\title{
Pemberdayaan ibu-ibu PKK pengolahan limbah minyak goreng bekas menjadi sabun cair di desa Sidorejo kabupaten Semarang
}

\author{
${ }^{1}$ Maria Mita Susanti*, ${ }^{2}$ Margareta Retno Priamsari \\ 1,2 D3 Farmasi, Politeknik Mangunwijaya, Semarang, Indonesia \\ *Corresponding Author \\ mythavia84@gmail.com
}

\begin{abstract}
Abstrak
Minyak goreng bekas merupakan limbah rumah tangga yang seringkali dibuang tanpa adanya pengolahan karena dianggap sudah tidak mempunyai nilai ekonomis lagi. Pelaksanaan program pengabdian ini bertujuan untuk membantu meningkatkan nilai ekonomis limbah minyak goreng bekas dengan menciptakan wirausaha baru (home industry) melalui peningkatan keterampilan dalam mengolah limbah. Program pengabdian dilaksanakan pada kelompok PKK RT 01 RW 09 desa Sidorejo, kecamatan Bergas kabupaten Semarang selama 6 bulan. Keaktifan kegiatan PKK desa Sidorejo dalam lingkup tersebut sangat baik, hal ini terlihat dari peran serta dan prestasi yang telah diraih sebagai juara 2 dalam lomba POSDAYA tingkat kabupaten Semarang. Dari pengamatan tim pengusul permasalahan yang dihadapi adalah belum maksimalnya pemanfaatan limbah minyak goreng bekas untuk didaur ulang menjadi produk yang mempunyai nilai guna dan nilai ekonomis. Metode yang dilakukan dalam kegiatan ini meliputi: 1) Sosialisasi dampak penggunaan minyak goreng bekas; 2) Pengenalan tentang pemanfaatan minyak goreng bekas; 3) Workshop pembuatan produk sabun cair dari bahan minyak goreng bekas. Hasil dari kegiatan ini memberikan kontribusi besar bagi ibu-ibu dan terbentuk suatu keterampilan baru dalam mengolah minyak goreng bekas sehingga terbentuk jiwa wirausaha.
\end{abstract}

Keywords: Minyak goreng bekas, sabun cair, wirausaha.

\begin{abstract}
Used cooking oil is household waste which is often disposed of without processing because it is considered to have no economic value anymore. The implementation of this service aims to help increase the economic value of used cooking oil waste by creating new industries (home industries) through increasing skills in processing waste. The service program was held in PKK RT 01 RW 09 Sidorejo Village, Bergas District, Semarang Regency for 6 months. The activeness of the Sidorejo village PKK activities in that scope is very good, this can be seen from the participation and achievements that have been achieved as runners-up in the POSDAYA competition at the Semarang district level. From the observation of the proposing team the problem faced was that the utilization of used cooking oil waste was not maximized to be recycled into products that have use value and economic value. The methods carried out in this activity include: 1) Dissemination of the effects of using used cooking oil; 2) Introduction to the use of used cooking oil; 3) Workshop on making liquid soap products from used cooking oil. The results of
\end{abstract}


this activity make a major contribution to mothers and new skills are formed in processing used cooking oil so that an entrepreneurial spirit is formed.

Keywords: Used cooking oil, liquid soap, entrepreneurship

\section{PENDAHULUAN}

Minyak goreng bekas atau minyak jelantah (waste cooking oil) adalah minyak yang telah digunakan secara berulang-ulang hingga 3-4 kali penggorengan (Naomi et al., 2013). Minyak goreng tersebut akan mengalami perubahan sifat fisika-kimia. Perubahan fisika (penurunan kualitas) pada minyak goreng ditandai dengan perubahan warna menjadi gelap dan aroma menjadi kurang enak, sedangkan perubahan kimia ditandai dengan adanya proses hidrolisis, oksidasi, polimerisasi, dan reaksi pencoklatan yang disebabkan karena pemanasan pada suhu tinggi. Proses oksidasi dan polimerisasi dapat merusak sebagian vitamin dan asam lemak esensial yang terdapat dalam minyak sehingga memberikan dampak yang berbahaya bagi kesehatan yang dapat mengakibatkan keracunan dalam tubuh dan berbagai penyakit, seperti diare, pengendapan lemak dalam pembuluh darah, dan kanker (Ketaren, 1986). Dampak negatif dari minyak goreng bekas jika dibuang begitu saja tanpa pengolahan akan menjadi limbah dan akan merusak lingkungan sekitar (Rosita dan Widasari, 2008).

Perubahan sifat minyak goreng yang digunakan secara berulang dapat menjadikan minyak tidak layak digunakan sebagai bahan makanan. Minyak goreng bekas merupakan limbah rumah tangga yang seringkali dibuang tanpa adanya pengolahan karena dianggap sudah tidak mempunyai nilai ekonomis. Pada dasarnya minyak goreng bekas dapat dimurnikan kembali dan dapat diolah menjadi alternatif bahan baku pembuatan sabun sehingga dapat meningkatkan nilai jual dari minyak goreng bekas. Oleh karena itu diperlukan adanya suatu usaha pengolahan minyak goreng bekas menjadi sebuah produk yang mempunyai nilai ekonomis yang tinggi. Salah satu bentuk produk hasil pengolahan minyak goreng bekas adalah sabun.

Sabun secara umum didefinisikan sebagai garam alkali dari asam lemak rantai panjang. Lemak atau minyak disaponifikasi bersama garam natrium atau kalium sehingga terjadi proses penyabunan. Sabun dihasilkan dari dua bahan utama, yaitu alkali dan lemak atau minyak (Anggraini, 2012). Salah satu minyak yang digunakan dalam komponen sabun adalah minyak goreng yang berasal dari nabati atau hewani (Naomi dkk, 2013). Sabun dapat dibuat berdasarkan proses saponifikasi, yaitu hidrolisis lemak menjadi asam lemak dan gliserol dalam kondisi basa. Basa yang biasa digunakan adalah natrium hidroksida $(\mathrm{NaOH})$ dan kalium hidroksida $(\mathrm{KOH}) . \mathrm{NaOH}$ biasa digunakan pada reaksi berupa sabun keras (padat), sedangkan 
$\mathrm{KOH}$ digunakan pada reaksi berupa sabun cair karena sifatnya yang mudah larut dalam air (Ketaren, 1986).

Muljadi (2012) menyatakan bahwa sabun cair dapat dibuat dari minyak goreng bekas dengan proses saponifikasi menggunakan $\mathrm{KOH} 40 \%$ pada temperatur $70^{\circ} \mathrm{C}$ dan variasi lama waktu proses penyabunan yaitu 60 menit, 90 menit dan 120 menit. Hasil penelitian menunjukan sabun cair yang memenuhi persyaratan yaitu sabun cair dengan lama waktu proses penyabunan 120 menit menggunakan konsentrasi $\mathrm{KOH}$ 40\%. Sabun cair dengan konsentrasi $\mathrm{KOH} 40 \%$ menghasilkan kadar alkali bebas $0,056 \%$, dan asam lemak bebas $0,16 \%$. Kegunaan $\mathrm{KOH}$ dalam pembuatan sabun cair yaitu membantu proses saponifikasi dan mempengaruhi karakteristik mutu sabun di antaranya kadar asam lemak bebas dan alkali bebas. Kadar asam lemak bebas dan alkali bebas yang tinggi menyebabkan iritasi pada kulit (Naomi dkk, 2013).

Sabun cair (dalam hal ini sabun cuci piring) merupakan salah satu produk rumah tangga yang setiap hari digunakan oleh masyarakat khususnya ibu-ibu yang guna untuk membersihkan berbagai peralatan memasak di dapur. Sabun cair cuci piring ini dapat dibuat dengan memanfaatkan limbah dari minyak goreng yang sudah tidak terpakai lagi. Menurut Randja (2010) minyak bekas penggorengan dapat menjadi bahan dasar untuk membuat sabun cair.

Penyuluhan mengenai pengolahan minyak goreng bekas kepada ibu-ibu merupakan salah satu bentuk kegiatan yang dapat mendukung keterampilan untuk menciptakan wirausahawan baru. Ibu-ibu rumah tangga mempunyai waktu yang cukup luang dalam melakukan kegiatan yang bersifat produktif. Kegiatan ini dapat berupaya untuk memanfaatkan waktu terutama bagi ibu rumah tangga dalam mengembangkan keterampilan sekaligus menjadi bekal untuk dapat meningkatkan ekonomi keluarga. Bentuk kegiatan tersebut dilakukan melalui pemberdayaan yang ada dalam kegiatan PKK, yaitu dengan memberikan sosialisasi berupa penyuluhan tentang bahaya penggunaan minyak goreng bekas sampai dengan memberikan keterampilan (workshop) untuk mengolah sisa minyak goreng menjadi sebuah produk yang dapat dimanfaatkan sehingga mempunyai nilai ekonomis yang cukup tinggi.

Pelaksanaan penyuluhan ini terdiri atas beberapa tahapan meliputi tahap pertama edukasi mengenai dampak kesehatan penggunaan minyak goreng bekas untuk memberikan pengetahuan tentang pengaruh kesehatan penggunaan minyak goreng bekas kemudian tahap kedua edukasi pengolahan limbah minyak goreng bekas, yaitu memberikan cara pengolahan minyak goreng bekas yang tepat sehingga dapat didaur ulang. Tahap ketiga penerapan metode pengolahan limbah minyak goreng bekas dengan menawarkan suatu metode alternatif untuk mengolah limbah minyak goreng bekas menjadi produk yang mempunyai nilai ekonomi yang tinggi dan mudah untuk dialplikasikan kepada masyarakat. 
Kegiatan penyuluhan pengolahan limbah minyak goreng bekas dilakukan di kelompok PKK desa Sidorejo. Kegiatan PKK yang selama ini telah berjalan di desa Sidorejo RT 1 RW IX meliputi pertemuan rutin tingkat RT maupun tingkat RW. Keaktifan kegiatan PKK di kelompok tersebut sangat baik, hal ini terlihat dengan prestasi yang didapat salah satunya adalah peran sertanya dalam kegiatan POSDAYA. Selain hal tersebut dari hasil observasi menunjukkan ketersediaan minyak goreng bekas didaerah tersebut melimpah karena minyak goreng bekas yang dihasilkan semua hanya dibuang begitu saja tanpa ada pengolahan lebih lanjut. Pengetahuan tentang dampak kesehatan menggunakan minyak goreng bekaspun masih terbatas serta belum mengetahui cara pengolahan minyak goreng bekas yang dapat dikembangkan menjadi produk yang mampu meningkatkan ekonomi keluarga. Melalui kegiatan PKK ini diharapkan menjadi wadah untuk penyaluran edukasi terkait pemanfaatan dan pengolahan limbah minyak goreng bekas menjadi produk yang mempunyai nilai guna dan nilai ekonomi tinggi yaitu menjadi produk "Sabun Cair".

\section{METODE}

Penerapan program pengabdian kepada masyarakat dilakukan pada kelompok ibu-ibu PKK, RT 01 RW 09 yang berlokasi di desa Sidorejo, kabupaten Semarang. Metode yang dilakukan berupa kegiatan penyuluhan, pelatihan pembuatan sabun cair dari bahan dasar minyak goreng bekas. Pelaksanaan kegiatan tersebut melalui empat tahap, mulai dari tahap pertama yaitu pendaftaran peserta, tahap kedua sosialisasi edukasi dampak kesehatan penggunaan minyak goreng bekas, tahap ketiga penyuluhan mengenai daur ulang minyak goreng bekas, dan tahap terakhir yaitu pelatihan pembuatan sabun cair.

Hasil dari pelaksanaan program pengabdian ini diharapkan mampu membuka wawasan masyarakat sehingga mampu meningkatkan nilai guna dan nilai ekonomis minyak goreng bekas. Disamping itu tercipta wirausaha (home industry) baru melalui peluang usaha dalam membuat produk sabun cair. Metode yang dilakukan pada kegiatan ini adalah memberi solusi berupa keterampilan atas permasalahan kurangnya pengolahan limbah minyak goreng bekas. Solusi yang ditawarkan oleh Tim Pelaksana program Pengabdian adalah sebagai berikut:

1. Edukasi mengenai dampak kesehatan penguunaan minyak goreng bekas

Pengetahuan yang kurang tentang dampak kesehatan penggunaan minyak goreng bekas menyebabkan masih banyaknya ibu-ibu yang secara berulang menggunakan minyak goreng bekas dalam mengolah makanan. Pada pengabdian ini salah satunya memberikan sosialisasi atau penyuluhan mengenai dampak kesehatan yang ditimbulkan dalam pengunaan minyak 
goreng bekas sehingga dapat menekan angka kesakitan akibat penggunaan minyak goreng yang berulang. Dampak kesehatan yang mungkin ditimbulkan akibat penggunaan minyak goreng secara berulang adalah penyakit kardiovaskular dan kanker.

2. Edukasi pengolahan limbah minyak goreng bekas

Pengetahuan yang kurang tentang manfaat dan cara pengolahan minyak goreng bekas menjadikan minyak goreng bekas hanya dibuang begitu saja tanpa pemanfaatan ulang. Pemberian edukasi berupa penyuluhan dapat mengubah paradigma masyarakat sehingga minyak goreng dapat diolah menjadi alternatif produk yang dapat diaplikasikan dalam masyarakat dan mempunyai nilai guna dan nilai ekonomi yang tinggi.

3. Penerapan metode pengolahan limbah minyak goreng bekas

Limbah minyak goreng bekas pada umumnya dibuang dan hanya dipandang sebelah mata. Tim pelaksana program pengabdian kepada masyarakat menawarkan suatu metode alternatif, yaitu mengolah limbah minyak goreng bekas menjadi produk yang mempunyai nilai ekonomi yang tinggi dan mudah untuk dialplikasikan kepada masyarakat. Dengan penerapan metode ini diharapkan nilai ekonomis dari limbah minyak goreng bekas dapat meningkat, disamping itu tercipta peluang usaha baru (home industry) sehingga dapat meningkatkan pendapatan ekonomi keluarga.

Jadwal kegiatan pengabdian kepada masyarkat ini dilaksanakan dalam waktu 6 bulan, yang terdiri atas beberapa tahapan kegiatan yang meliputi:

1. Pendaftaran peserta yang berasal dari ibu-ibu PKK desa Sidorejo, kabupaten Semarang Pendaftaran peserta terbuka bagi seluruh anggota kelompok ibu-ibu PKK RT 01 RW 09 desa Sidorejo, kabupaten Semarang. Sosialisasi program ini dilakukan pada saat pertemuan rutin PKK oleh Kader PKK setempat.

2. Edukasi mengenai dampak kesehatan penggunaan minyak goreng bekas

Edukasi ini disampaikan untuk mengurangi penggunaan minyak goreng bekas sehingga menghindari terjadinya dampak kesehatan yang merugikan.

3. Penyuluhan mengenai daur ulang minyak goreng bekas

Kegiatan penyuluhan ini dilakukan untuk memberikan edukasi kepada ibu-ibu PKK tentang bagaimana memanfaatkan minyak goreng bekas menjadi produk alternatif yang mempunyai nilai guna dan ekonom. Tujuannya untuk mengubah paradigma masyarakat yang selama ini menganggap minyak goreng hanya sebagai limbah yang tidak dapat didaur ulang dan digunakan kembali. 
4. Pelatihan pembuatan sabun cair

Pelatihan pembuatan sabun cair ini dilakukan supaya ibu-ibu PKK mampu menerapkan keterampilan mengolah limbah minyak goreng bekas menjadi alternatif produk daur ulang.

Berdasarkan hasil wawancara dan kesepakatan bersama maka bentuk partisipasi kedua mitra yang dapat menunjang kelancaran pelaksanaan program pengabdian kepada masyarakat adalah sebagai berikut:

1. Menyediakan tempat untuk kegiatan penyuluhan.

2. Menyediakan tempat pelatihan pembuatan sabun cair.

3. Menyediakan sampel bahan baku berupa minyak goreng bekas.

\section{HASIL DAN PEMBAHASAN}

Kegiatan pengabdian kepada masyarakat mengenai pengolahan limbah minyak goreng bekas menjadi sabun cair ini, dilakukan pada kelompok ibu-ibu PKK di desa Sidorejo kabupaten Semarang dengan jumlah peserta yaitu 20 orang. Dari hasil pendataan awal kegiatan pengabdian ini didapatkan data bahwa ketersediaan minyak goreng bekas didaerah tersebut melimpah karena minyak goreng bekas yang dihasilkan semua hanya dibuang begitu saja tanpa ada pengolahan lebih lanjut. Pengetahuan tentang dampak kesehatan menggunakan minyak goreng bekaspun masih terbatas serta sebagian besar peserta belum mengetahui bagaimana cara pengolahan terhadap minyak goreng bekas sehingga dapat meningkatkan nilai secara ekonomi dan mampu menghasilkan produk yang mempunyai potensi untuk dikembangkan menjadi produk yang dapat meningkatkan ekonomi keluarga. Hasil pengolahan minyak goreng bekas dapat diolah menjadi sabun cair cuci piring yang selanjutnya dapat dikemas dan dipasarkan sehingga menjadi peluang berwirausaha bagi peserta. Dengan demikian respon ibu-ibu PKK sangat baik dalam mengukuti pelatihan dan dapat meningkatkan semangat untuk aktif mengikuti pelatihan ini.

\section{Sosialisasi Dampak Kesehatan Penggunaan Minyak Goreng Bekas}

Kegiatan penyuluhan diawali dengan sosialisasi dampak kesehatan yang ditimbulkan dari penggunaan minyak goreng bekas, dengan sosialisasi ini diharapkan ibu-ibu mulai menyadari tentang pentingnya kesehatan terlebih terkait dengan penggunaan minyak goreng bekas dalam mengolah makanan sehari-hari. Kegiatan sosialisasi dampak kesehatan disajikan pada Gambar 1 dan Gambar 2. 


\section{Indonesian Journal of Community Services}

E-ISSN: 2684-8619

Volume 1, No. 1, May 2019

http://jurnal.unissula.ac.id/index.php/ijocs DOI: http://dx.doi.org/10.30659/ijocs.1.1. 48-61

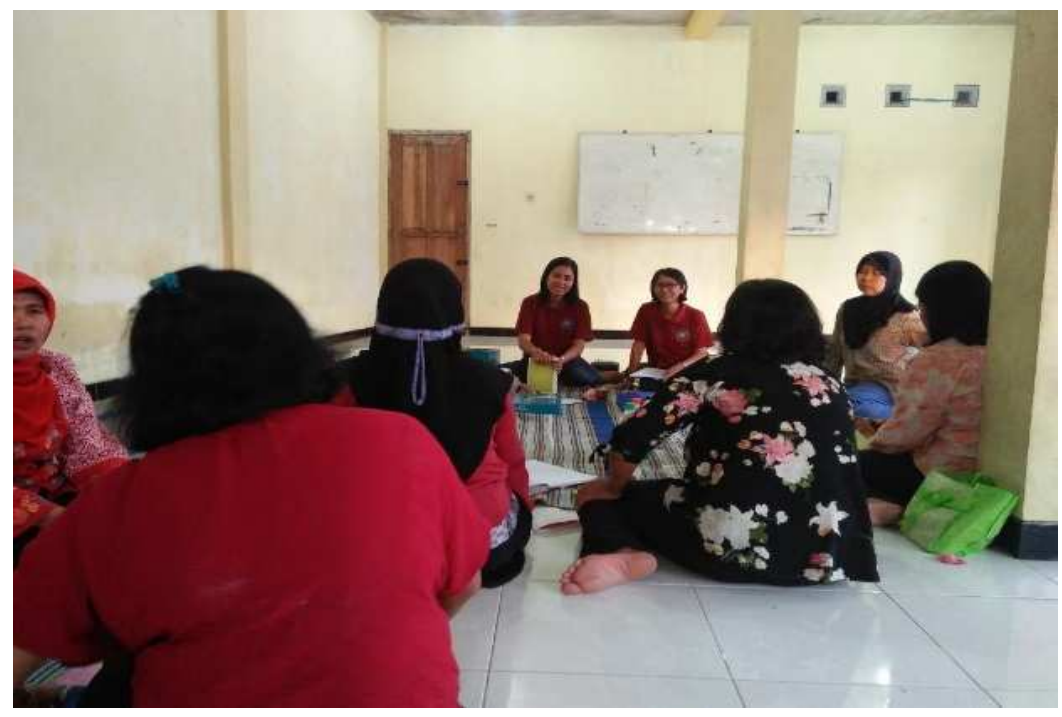

Gambar 1. Sosialisasi dampak kesehatan.

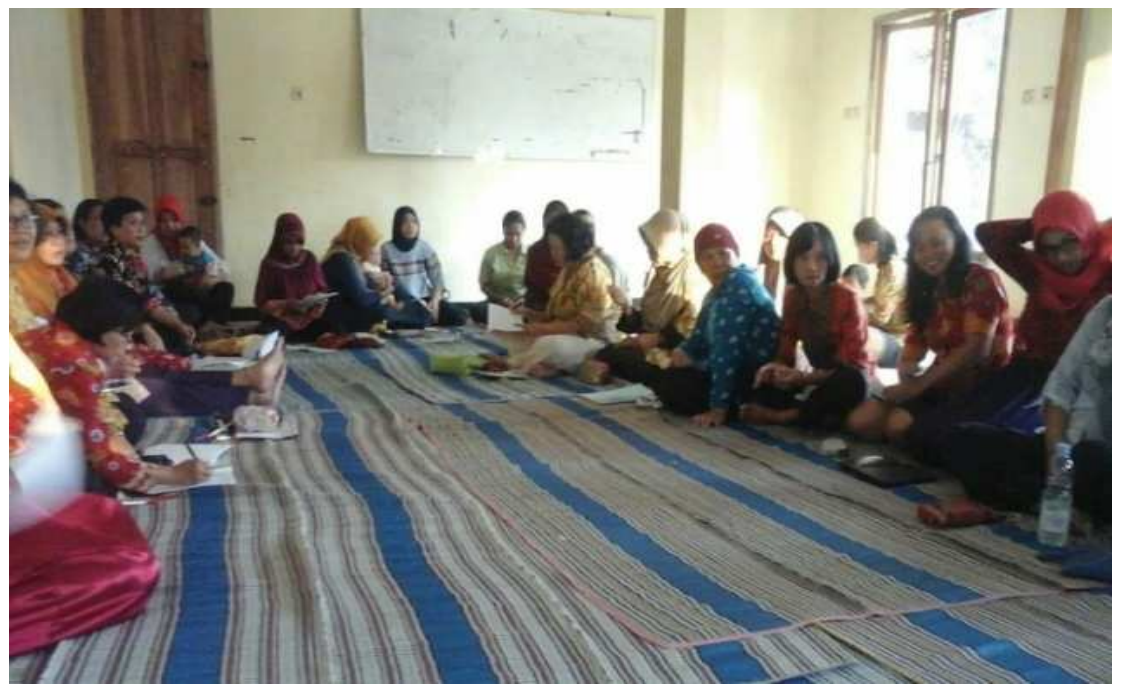

Gambar 2. Keterlibatan mitra pada kegiatan sosialisasi.

\section{Pembuatan Sabun}

Pemurnian merupakan tahap awal dari proses pemanfaatan minyak goreng bekas untuk digunakan kembali sebagai alternatif bahan baku suatu produk. Tujuan utama dari pemurnian minyak goreng bekas atau minyak jelantah adalah menghilangkan rasa dan bau yang tidak enak serta warna yang kurang menarik. Pemurnian minyak goreng ini meliputi 3 tahapan proses, yaitu penghilangan bumbu (despicing), netralisasi, dan pemucatan (bleaching), adapun proses pemurnian minyak goreng bekas adalah sebagai berikut: 
1. Penghilangan kotoran (despicing)

Air sebanyak 500 gram dipanaskan, kemudian ditambahkan 500 gram minyak jelantah. Campuran dipanaskan pada suhu $110^{\circ} \mathrm{C}$ hingga volume air menjadi setengah dari volume awal. Kemudian larutan dimasukkan kedalam corong pisah dan diendapkan selama 1 jam. Kemudian diambil fase minyak lalu dilakukan penyaringan menggunakan kertas saring (Ketaren, 2005). Minyak goreng bekas pada proses penghilangan kotoran dipanaskan untuk menghilangkan partikel halus tersuspensi seperti protein, garam, gula, dan bumbu rempahrempah. Pemanasan menggunakan akuades bertujuan untuk menarik kotoran yang besifat polar atau larut air sehingga akan mengendap di bawah bersama fase air (Aisyah, 2010).

2. Proses netralisasi

Minyak goreng hasil despicing sebanyak 450 gram dipanaskan pada suhu $\pm 35^{\circ} \mathrm{C}$, kemudian ditambahkan larutan $\mathrm{NaOH} 10 \%$ hingga larutan netral ( $\mathrm{pH}$ 7), suhu ditingkatkan hingga $40^{\circ} \mathrm{C}$. Lalu campuran diaduk selama 10 menit, dan didiamkan selama 10 menit kemudian disaring dengan kertas saring untuk memisahkan kotoran (Ketaren, 2005). Proses netralisasi bertujuan untuk memisahkan asam lemak bebas dari minyak dengan cara mereaksikan asam lemak bebas dengan basa sehingga bersifat netral. Asam lemak bebas dalam minyak goreng bekas memiliki gugus asam karboksilat yang bersifat asam. Pada proses netralisasi dilakukan dengan mereaksikan minyak goreng bekas dan $\mathrm{NaOH}$ sampai $\mathrm{pH} 7$ atau netral. Reaksi dengan $\mathrm{NaOH}$ berlangsung melalui serangkaian tahap protonasi deprotonasi. Oksigen karbonil diprotonasi, $\mathrm{NaOH}$ nukleofil menyerang karbon positif dan menghasilkan garam karboksilat (Septono dan Utami, 2011).

\section{Proses pemucatan (Bleaching)}

Minyak hasil netralisasi sebanyak 200 gram dipanaskan pada suhu $70^{\circ} \mathrm{C}$ dan ditambahkan karbon aktif sebanyak 75 miligram lalu suhu ditingkatkan menjadi $100^{\circ} \mathrm{C}$ selama 60 menit. Kemudian campuran didinginkan dan disaring dengan kain flannel. Penyaringan dilanjutkan kembali dengan menggunakan kertas saring untuk memisahkan minyak dari karbon aktif (Yulianti, 2009). Proses pemucatan dilakukan untuk menjernihkan warna dan menghilangkan bau pada minyak goreng bekas dengan cara memanaskan minyak dengan suhu $70^{\circ} \mathrm{C}$, kemudian ditambahkan serbuk arang aktif $150 \mathrm{mg}$ dengan pengadukan hingga mencapai suhu $100 \square$ untuk mempercepat reaksi antara arang aktif dengan minyak goreng bekas. Tujuan digunakan arang aktif yaitu memperbesar kapasitas adsorben karena terbukanya pori-pori arang setelah diaktifkan sehingga menghilangkan zat-zat warna dan menghilangkan bau (Hajar, 2016). Sedangkan pengadukan dilakukan untuk mempercepat proses adsorpsi sehingga mencapai kesetimbangan dan dimaksudkan untuk memberi 
Indonesian Journal of Community Services

E-ISSN: 2684-8619

Volume 1, No. 1, May 2019

http://jurnal.unissula.ac.id/index.php/ijocs DOI: http://dx.doi.org/10.30659/ijocs.1.1. 48-61

kesempatan arang aktif untuk bersinggungan dengan senyawa serapan (Naomi dkk, 2013).

Hasil dari pemurnian minyak goreng bekas disajikan pada Gambar 3.

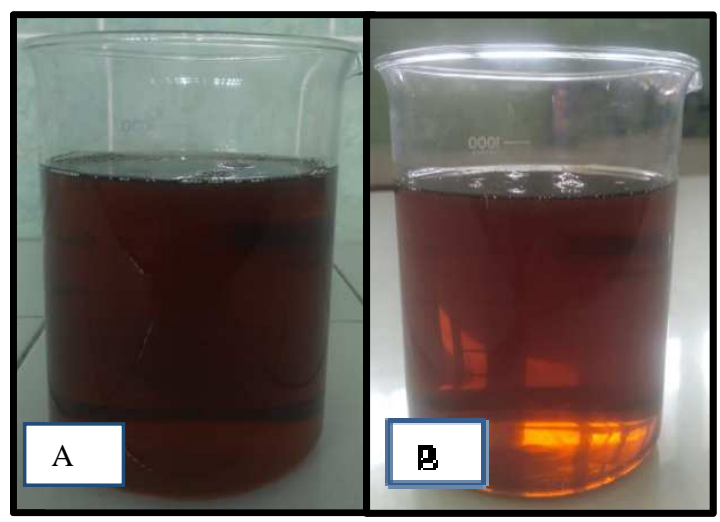

Gambar 3. A) Minyak goreng bekas sebelum pemurnian.

B) Minyak goreng bekas sesudah pemurnian.

Minyak goreng bekas yang telah dimurnikan selanjutnya dilakukan pengolahan menjadi produk sabun cair. Minyak goreng bekas (minyak jelantah) hasil pemurnian dan $\mathrm{NaOH}$ dicampur dan dipanaskan pada suhu $60^{\circ} \mathrm{C}-80^{\circ} \mathrm{C}$ hingga proses saponifikasi berlangsung sempurna dan ditandai dengan tercapainya base sabun (Susanti, M.M dan Gutterres, A.D.A, 2018). Lalu ditambahkan Texapon sambil diaduk hingga base sabun tampak transparan kemudian ditambahakan larutan asam sitrat untuk mengendalikan $\mathrm{pH}$ sabun setelah membentuk larutan sabun sesuai dengan kosnsistensi yang diinginkan terakhir ditambahkan pewarna alami kemudian diaduk. Sabun cair yang telah terbentuk ditambahkan oleum citrus sebagai penambah aroma sabun. Proses pembuatan base sabun disajikan pada Gambar 4 berikut.

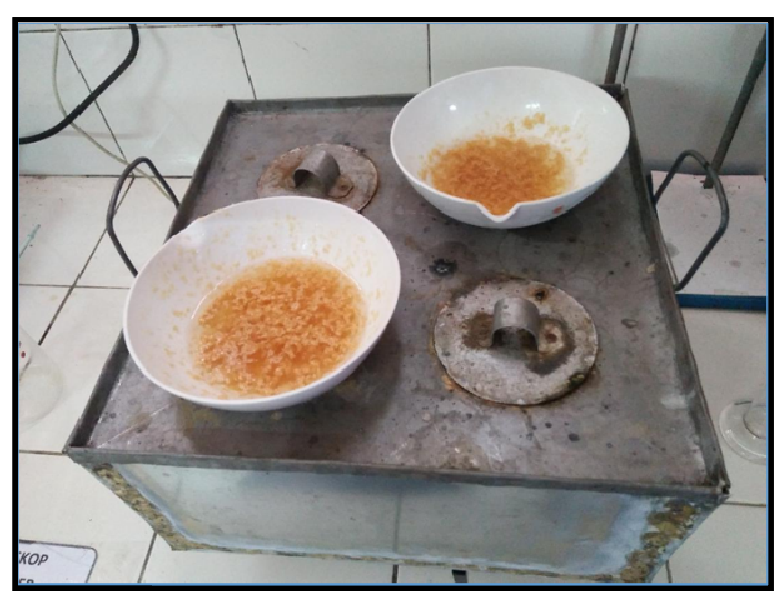

Gambar 4. Proses pembuatan base sabun. 
Pada proses saponifikasi antara minyak goreng bekas dengan basa ini kemudian terbentuk base sabun padat. Pemilihan $\mathrm{KOH}$ sebagai basa karena basa $\mathrm{KOH}$ paling sering digunakan dalam pembuatan sabun cair serta membantu proses saponifikasi (Hajar, 2016). Proses pemanasan dan pengadukan dilakukan untuk memperluas tumbukan partikel antar zat yang terjadi sehingga reaksi berlangsung cepat. Semakin lama waktu pengadukan maka semakin banyak jumlah base sabun yang dihasilkan (Naomi dkk, 2013). Base sabun disajikan pada gambar 5 berikut.

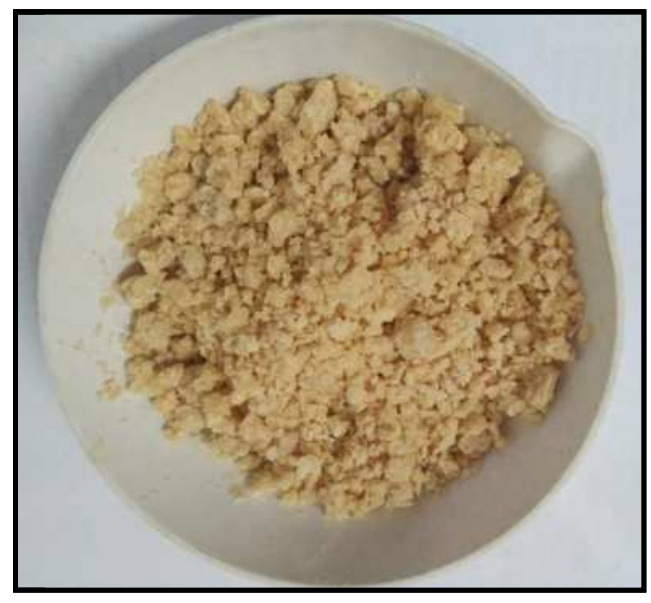

Gambar 5. Proses base sabun.

Setelah proses pembuatan base sabun, langkah selanjutnya dengan memanaskan kembali base sabun yang telah terbentuk dengan menggunakan larutan asam sitrat untuk mendapatkan konsistensi larutan sabun yang dikehendaki sekaligus untuk mengatur nilai $\mathrm{pH}$ sabun supaya $\mathrm{pH}$ sabun berkisar antara 9-10 sehingga tidak mengiritasi kulit pada saat digunakan. Nilai $\mathrm{pH}$ dalam sediaan sabun cair mepengaruhi kenyamanan pemakaian pada saat diaplikasikan. Derajat keasaman $(\mathrm{pH})$ yang sangat tinggi atau rendah dapat meningkatkan daya absorbsi kulit sehingga menyebabkan iritasi pada kulit dan kulit kering. $\mathrm{pH}$ sediaan sabun cair memenuhi persyaratan yang telah ditetapkan, karena batas penerimaan $\mathrm{pH}$ sabun cair cuci adalah 8,5 - 10,5 (Narkhede, 2010). Hasil produk sabun disajikan pada Gambar 6 sebagai berikut. 


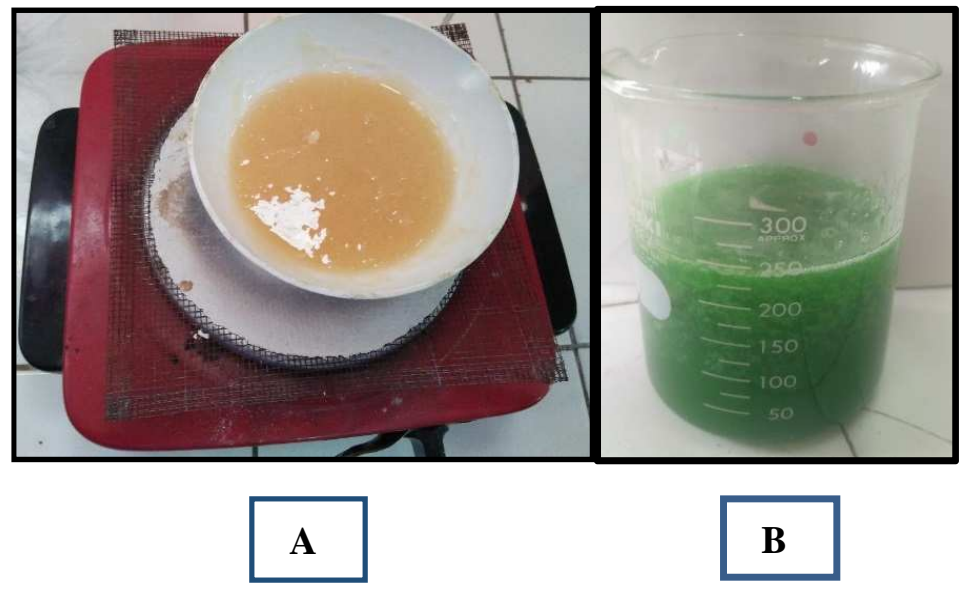

Gambar 6. A) Produk sabun cair sebelum pewarnaan.

B) Produk sabun cair setelah pewarnaan.

\section{Pengenalan Tentang Pemanfaatan Minyak Goreng Bekas}

Setelah formulasi produk sabun minyak goreng bekas selesai, kegiatan selanjutnya dengan mengagendakan kegiatan pengenalan sabun yang dibuat dari bahan dasar minyak goreng bekas kepada masyarakat di desa Sidorejo. Pengenalan produk ini bertujuan untuk memberikan edukasi kepada masyarakat bahwa minyak goreng bekas yang dianggap sebagai limbah tenyata masih dapat diolah kembali menjadi produk yang memiliki nilai guna dan nilai ekonomis yang tinggi. Salah satunya sebagai alternatifnya adalah sebagai bahan dasar pembuatan sabun.

Penggunaan minyak goreng tidak diperbolehkan melebihi dari 3 kali penggorengan karena akan mengalami perubahan fisika dan kimia yang akan mengakibatkan gangguan kesehatan. Menurut Nuryanti (2017), hasil asam lemak bebas dari minyak goreng bekas penggunaan 3 kali penggorengan tidak lebih dari 2,5\% sesuai dengan SNI (1990). Hasil kegiatan pengenalan disajikan pada gambar 7 sebagai berikut.

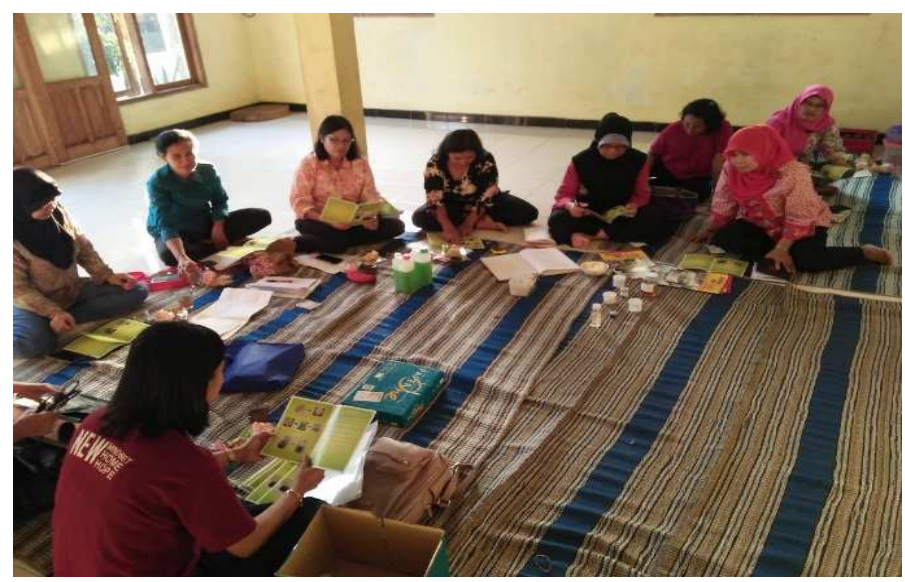

Gambar 7. Pengenalan produk sabun. 
Volume 1, No. 1, May 2019

http://jurnal.unissula.ac.id/index.php/ijocs DOI: http://dx.doi.org/10.30659/ijocs.1.1.48-61

\section{Pengolahan Minyak Goreng Bekas Menjadi Sabun Cair}

Tahap selanjutnya setelah pengenalan produk yaitu pelatihan pembuatan sabun dengan menggunakan bahan dasar minyak goreng bekas. Pada pelatihan ini masyarakat diminta keterlibatannya untuk membawa minyak goreng bekas yang telah dipakai maksimal adalah tiga kali penggorengan karena pada tiga kali penggorengan asam lemak bebas yang terbentuk masih tidak terlalu tinggi sehingga masih dapat dimurnikan untuk dijadikan sebagai bahan baku pembuatan sabun cair. Pelatihan pembuatan sabun cair bersama dengan mitra disajikan pada Gambar 8.

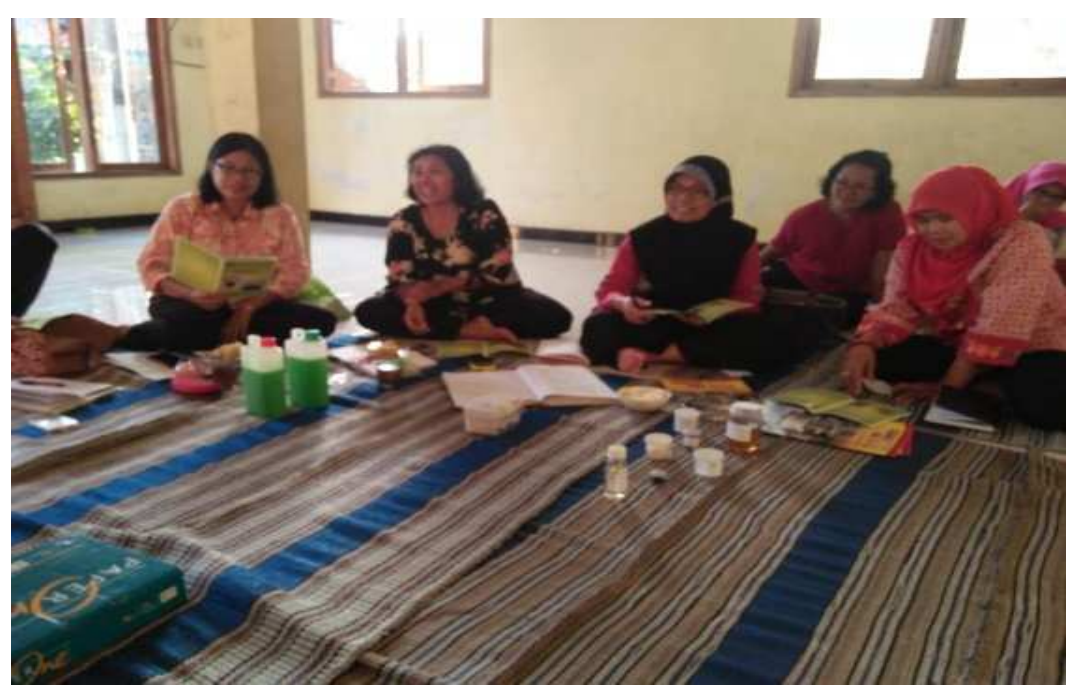

Gambar 8. Pelatihan pembuatan sabun cair.

\section{KESIMPULAN}

Kegiatan pengabdian kepada masyarakat ini mendapatkan respon positif dari ibu-ibu PKK RT 01 RW 09, hal ini dilihat dari tingginya minat masyarakat mengikuti kegiatan tersebut dan banyaknya pertanyaan yang disampaikan. Pada akhir pelatihan dibuat produk sabun cair yang kemudian dibagi-bagikan kepada ibu-ibu untuk digunakan secara pribadi. Mereka berharap keterampilan yang diperoleh dapat lebih dikembangkan lagi, dengan harapan bisa memberikan manfaat finansial.

Tahap berikutnya satu tahun setelah pelaksanaan kegiatan pengabdian diharapkan perlu dilakukan langkah-langkah strategis untuk pengembangan produk ini, antara lain pengurusan ijin edar produk dan penggunaan teknologi elektronik yang dapat membantu pendistribusian dari produk. Langkah-langkah strategis tersebut bertujuan untuk pengembangan seperti kegiatan pemasaran supaya konsumen dengan mudah mendapatkan produknya. Hal-lain yang perlu direncanakan adalah membuat tim produksi yang bertugas untuk membuat produk sabun secara 
berkala. Tim ini nantinya akan dibagi beberapa kelompok untuk secara bergantian menyiapkan dan mengumpulkan bahan baku sabun seperti minyak goreng bekas dan bertugas untuk memproduksi sabun.

\section{UCAPAN TERIMA KASIH}

Penulis mengucapkan terima kasih kepada:

1. Mitra kegiatan pengabdian warga desa Sidorejo RT 01 RW 09, kecamatan Bergas kabupaten Semarang yang telah berkontribusi atas waktu dan tempat sehingga kegiatan pengabdian dapat terlaksana.

2. Politeknik Katolik Mangunwijaya yang telah mendanai kegiatan pengabdian kepada masyarakat sehingga kegiatan ini dapat terselesaikan.

\section{DAFTAR PUSTAKA}

Anggraini, D., Wiwik, dan Masril. (2012). Formulasi Sabun Cair dari Ekstrak Batang Nanas (Ananascomosus. L) untuk Mengatasi Jamur Candida albicans. Jurnal Penelitian Farmasi Indonesia.

Badan Standarisasi Nasional. (1994). SNI 06-3532-1994 Standar Mutu Sabun Mandi. Jakarta: Dewan Standarisasi Nasional.

Badan Pusat Statistik, Kabupaten Semarang. (2013).

Hajar, E. dan Mufidah, S. (2016). Penurunan Asam Lemak Bebas Pada Minyak Goreng Bekas Menggunakan Ampas Tebu Untuk Pembuatan Sabun. Jurnal Integrasi Proses Vol. 6, No. 1 (Juni 2016) $22-27$.

Ketaren,S. (2015). Pengantar Teknologi Minyak dan Lemak. UI Press. Jakarta.

Muljadi, N. M. S., Kurniawati, Y., (2012). Pembuatan Sabun Cair Dari Minyak Jelantah Dengan Proses Saponifikasi Menggunakan KOH. Jurnal Teknik Kimia.

Narkhede, D.B., (2010). Formulation and Evaluation of Coconut Oil Liquid Soap. International Journal Pharma World Researc.

Naomi, P., Gaol, A.M.L., \& Toba, M.Y. (2013). Pembuatan Sabun Lunak Dari Minyak Goreng Bekas Ditinjau Dari Kinetika Reaksi Kimia, Jurnal Teknik Kimia Nomor 2, Volume 19, April 2013. Universitas Sriwijaya: Palembang.

Prawira. (2010). Reaksi Saponifikasi Pada Proses Pembuatan Sabun. Penebar Swadaya: Jakarta.

Randja A.F., Febrina.L., \& Krisdianto. D. (2010). Pemurnian Minyak Jelantah Menggunakan Ampas Tebu Sebagai Adsorben. Jurnal Teknik Kimia Nomor 1. Volume 17. Universitas Sriwijaya. 
Indonesian Journal of Community Services

E-ISSN: 2684-8619

Volume 1, No. 1, May 2019

http://jurnal.unissula.ac.id/index.php/ijocs DOI: http://dx.doi.org/10.30659/ijocs.1.1.48-61

Rosita, dan Widasari, WA. (2008). Peningkatan Kualitas Minyak Goreng Bekas dari KFC dengan Menggunakan Adsorben Karbon Aktif. Disertasi. Universitas Diponegoro.

Susanti, S., Fahjar, P., \& Ari, W. (2014). Minyak Jelantah Sebagai Bahan Baku Pembuatan Sabun Transparan. UHAMKA: Jakarta

Susanti, M.M \& Guterres A.D.A. (2018). Pengaruh Penambahan Kalium Hidroksida (KOH) Terhadap Mutu Sabun Lunak Berbahan Dasar Minyak Goreng Bekas. Jurnal Ilmiah Medsains, Volume 4 Nomor 01, Desember 2018. ISSN 2442-8752. Politeknik Banjarnegara.

Tomskaya, L.A., Makarova, N.P., \& Ryabov, V.D. (2008). Determination of The Hydrocarbon composition of crude oils. Chem Tech Fuel Oil.

Wijana, S. (2005). Mengolah Minyak Goreng Bekas. Trubus Agrisana: Surabaya.

Yulianti, E. (2009). Adsorbsi Peroksida dan Asam Lemak Bebas (FFA) dalam (Moringa oliefera Lamk) yang telah Diaktivasi dengan Proses Pirolisis Satu Tahap. Jurnal Teknik Kimia Volume 1, Nomor 2, Lamlitbang, Fakultas Sains Universitas Islam Negeri Malang, Malang. 